\title{
Yield of Male Touch DNA from Fabrics in an Assault Model
}

\author{
Vishi Sethi ${ }^{1,2}$, Edward A Panacek ${ }^{1,3}$, William M Green ${ }^{1,4}$, Jillian NG ${ }^{1,2}$ and Sree Kanthaswamy ${ }^{1,2,5 *}$
}

${ }^{1}$ Forensic Science Graduate Program, University of California Davis, USA

${ }^{2}$ Molecular Anthropology Laboratory, Department of Anthropology, University of California Davis, USA

${ }^{3}$ Department of Emergency Medicine, University of California Davis Medical Center, Sacramento, USA

${ }^{4}$ California Clinical Forensic Medical Training Center, USA

${ }^{5}$ Department of Environmental Toxicology, University of California Davis, USA

\begin{abstract}
Touch DNA evidence is increasingly being collected and analyzed during criminal investigations. The purpose of this study was to determine if a significant amount of male (suspect) touch DNA can be collected from the clothes of assaulted victims after varying time intervals. A "grab and struggle" model was used to transfer touch DNA materials from human volunteers onto three types of fabrics (cotton, polyester, and a cotton/polyester blend). This was designed to replicate a sexual assault, in which a male acted as an "assailant" and grabbed different fabric covered arm areas of a female volunteer "victim". Afterwards, three cuttings from each fabric sample were taken and extracted at 12 hours and 7 days post-deposition. The extracts were then quantified using the Quantifiler ${ }^{\mathbb{B}}$ Duo DNA quantification kit. The maximum yield of DNA from cotton fabric 12 hours post-deposition was $7 \mathrm{pg} / \mathrm{ul}$ and $5 \mathrm{pg} / \mathrm{ul}$ for total human DNA and human male DNA, respectively. The limit of detection of the Quantifiler Duo kit is $23 \mathrm{pg} / \mathrm{ul}$, therefore these results are below standard profile detection range. No significant deterioration of DNA yield between the two time intervals (12 hours and 7 days) was observed. Variation between the tested fabrics and the areas of sampling could not be determined due to the very small quantities measured.
\end{abstract}

This study did not find useful amounts of touch DNA on clothes after this assault model. Results are limited by a relatively small sample size and the assault model parameters; however, these results do not support the routine use of touch DNA evidence from clothes in similar assault cases.

Keywords: Touch DNA; Sexual assault; Fabrics; DNA quantification; Quantitative real-time polymerase chain reaction (qPCR)

\section{Introduction}

Humans shed skin cells which are often deposited as they contact physical objects. DNA obtained from cells transferred from a person to another object is called touch DNA. Touch DNA is often known as low copy number (LCN) DNA [1] and is increasingly being used as evidence in forensic casework [2,3]. Extensive efforts have been made to collect touch DNA from numerous substrates; such as human skin, interiors of latex gloves, lip prints, steering wheels, door handles, and tool grips and shafts [3-8]. Among possible substrates, clothing is often thought to be a source of important evidence for forensic DNA analysis in criminal investigations, e.g. in sexual assault cases [9]. It is known that touch DNA can be recovered from the bodies and clothing of rape victims, but useful profiles are difficult to acquire since touch DNA is usually deposited in small amounts compared to bloodstains or other bodily fluids[10]. A challenge in touch DNA analysis is to ensure items being examined as evidence fit the context of the crime. For example, during investigation of a potential sexual assault crime, forensic examiners would generally focus on searching and collecting skin cells from reported areas of contact on the victim's skin and clothing.

Various collection techniques are used to acquire touch DNA from fabrics. The most common include cutting out a small section of fabric, or using adhesive tapes on fabric and then cutting a small section of tape, or rubbing a sterile cotton swab over the fabric and then cutting the tip of the swab [11]. After collection, the key steps involved in analyzing the samples are extraction, quantification, and STR profiling. In the past, forensic laboratories have used several extraction methods such as Chelax [12], solid phase [13], and organic solvents [14]. However, commercially available extraction kits have increased in popularity and utility through the reduction of contamination and loss of DNA associated with frequent tube changes during the extraction process [11].

Many researchers $[11,15-17]$ have extracted and typed partial and full DNA profiles from touched items, but none have quantified the DNA before STR profiling. Especially with shorter and degraded fragments of touch DNA, quantification can be a vital step of consideration prior to STR typing. Quantification determines whether the sample contains sufficient amounts of DNA for reliable STR analysis [15]. Full DNA profiles require minimum DNA concentrations of $0.5 \mathrm{ng} / \mathrm{ul}$ to $1 \mathrm{ng} /$ ul [6]. Concentrations below this range may either yield a partial DNA profile or no DNA profile at all. Commercially available STR-typing kits are quite expensive and it is cost prohibitive to run samples that will not provide complete STR profiles.

Since touch DNA is deposited in minute amounts of less than 100 pg, various factors can influence successful recovery. Lowe et al. [16] observed that an individual's tendency to deposit DNA varies with time since hand washing and the hand (dominant or non-dominant) that was used. Raymond et al. [17] observed that the persistence of trace DNA in an environment depended on the time until detection. Linacre

*Corresponding author: Sree Kanthaswamy, Department of Anthropology, University of California Davis, One Shields Avenue Davis, CA 95616, USA, Tel: 530-752-1588; Fax: 530-752-8885; E-mail: skanthaswamy@ucdavis.edu

Received November 15, 2013; Accepted November 20, 2013; Published November 23, 2013

Citation: Sethi V, Panacek EA, Green WM, Jillian NG, Kanthaswamy S (2013) Yield of Male Touch DNA from Fabrics in an Assault Model. J Forensic Res T1: 001. doi:10.4172/2157-7145.T1-001

Copyright: (c) 2013 Sethi V, et al. This is an open-access article distributed under the terms of the Creative Commons Attribution License, which permits unrestricted use, distribution, and reproduction in any medium, provided the original author and source are credited. 
et al. [11] reported that the quality of DNA profiles obtained from clothing could depend on the nature of the material.

The purpose of this study was to quantify the amounts of male specific touch DNA recovered from three types of fabrics (cotton, polyester, and a cotton/polyester blend) using a simulated "grab and resist" assault model; and to determine if sufficient yields of cellular material can be obtained from for successful STR profiling. Secondary goals were to determine if the amount of DNA detected varies by the time from deposition until collection, between the different fabrics.

\section{Materials and Methods}

\section{Sample collection}

The study involved four volunteer subjects - three males and one female within the ages of 20 to 35 . The subjects could not have skin defects or skin diseases and could not be taking prescribed medications. Throughout the study, male subjects were referred to as "assailants" and the female subject was referred to as "the victim". Three fabrics were used in this study; $100 \%$ cotton, $100 \%$ polyester, and a $60 \%$ cotton $/ 40 \%$ polyester blend. Each fabric was cut into three pieces and sterilized with ultra violet light for 10 minutes to destroy any extraneous cellular material. The sterilized pieces of each fabric type were wrapped around the victim's arm at three different areas: the wrist, elbow, and upper arm (area between the shoulder and the elbow). These areas simulated normal clothes on females. After fabric fragments were wrapped around the female subject's arms, male volunteers were asked to perform a scripted grab maneuver on the female subject. Fifteen minutes prior to grabbing, male subjects washed their hands with soap and warm water, to remove any extraneous cells or materials on their skin, and did not wear gloves. For the grabbing simulations, male participants were asked to grab the three fabric covered arm areas of the female participant for 15 seconds while she struggled to get out of their grip. The simulated grabbing was repeated with each male participant for the three different fabric types and two time intervals. Samples were collected and individually sealed in paper bags with duct tape and stored in a secured location prior to processing. This process was meant to replicate usual evidence collection procedures in assault investigations. The first set of samples was processed 12 hours after collection and the second set after 7 days. Buccal swabs were collected from each subject as positive DNA controls.

\section{Shedding ability assessment}

Shedder status of the volunteers was tested based on the methodology of Lowe et al. [16]. All four subjects were asked to wash their hands with soap and warm water prior to grabbing a $50 \mathrm{ml}$ conical tube, previously sterilized using UV irradiation, for 10 seconds. Tubes were swabbed before (negative control) and after contact with a sterilized swab (Epicenter Biotechnologies, Madison, WI) moistened with molecular grade water. This "holding-tube" procedure was repeated with each subject at three different time intervals post-hand washing: 0 seconds, 15 minutes, and 2 hours. The swabs were extracted and quantified to determine the DNA yield and shedder status of each volunteer.

\section{Sample extraction}

Samples were extracted using the QIAamp ${ }^{\circledR}$ DNA Micro kit (Qiagen, Valencia, CA). The first set of fabric samples was extracted 12 hours after collection and the second set after 7 days. Three cuttings of approximately $0.5 \mathrm{~cm}^{2}$ were cut from each fabric sample from each arm area for extraction. Swab tips from the reference buccal samples and shedder status assessment were cut for extraction. DNA isolation was performed following the manufacturer's procedure for DNA extraction from materials in forensic case work samples. Thirty micro liters of $\mathrm{AE}$ buffer was used for the final elution. Extracts from the same fabric type and arm area were pooled for a total volume of $75 \mathrm{ul}$. Samples from all fabrics and time intervals were processed in the same way. Extracted samples were concentrated using a Savant DNA 120-115 Speed Vac (Thermo Fisher Scientific Inc., Waltham, MA) and rehydrated with $\mathrm{ddH}_{2} \mathrm{O}$ for a final volume of $10 \mathrm{ul}$. Concentrating samples ensured that sufficient quantity and quality of DNA could be isolated from samples of interest.

\section{Sample quantification}

All extracts were quantified using the Quantifiler ${ }^{\circledR}$ Duo DNA Quantification kit (Applied Bio systems, Foster City, CA) and the Applied Bio systems ${ }^{\circledR} 7500$ Fast Real-Time PCR System (Applied Bio systems). Quantification standards and samples were run in duplicate following manufacturer protocols. DNA quantification standards are necessary for determining the DNA concentration of the samples. The Quantifiler $^{\circledR}$ Duo kit contains three different dye labeled TaqMan ${ }^{\circledR}$ probes targeting the human specific Ribonuclease P RNA Component H1 (RPPH1) gene, human male specific Sex-determining region Y (SRY) gene, and an internal positive control (IPC).

\section{Results}

The shedder status assessment of the subjects yielded variable amounts of human and male-specific DNA at different time intervals (Table 1). Of the three male subjects, only one subject (assailant 2) yielded male-specific DNA above the Quantifiler ${ }^{\circledR}$ Duo detection threshold of $7.0 \mathrm{pg} / \mathrm{ul}$, i.e. with $7.0 \mathrm{pg} / \mathrm{ul}$ of total human and malespecific DNA at 0 hours and $17.0 \mathrm{pg} / \mathrm{ul}$ of total human and $8.0 \mathrm{pg} /$ ul of male-specific DNA at 2 hours post-hand washing. Lower, below threshold amounts were observed for the other two male subjects (assailants 1 and 3) at the three time intervals. It is noteworthy that these results are out of the range of the standard curve because the limit of detection of the Quantifiler ${ }^{\circledR}$ Duo kit is $23 \mathrm{pg} / \mathrm{ul}$. At 2 hours, the amount of male-specific DNA for these two subjects exceeded the amount of total human DNA (Table 1). The shedder assessment for the female subject did not detect any trace of male DNA and yielded concentrations of $5.0,13.0$, and $9.0 \mathrm{pg} / \mathrm{ul}$ of total human DNA at 0 seconds, 15 minutes, and 2 hours, respectively. Reference buccal swab samples yielded ample amounts of human genomic DNA with male reference samples yielding an equal amount of human and malespecific DNA content of $35.0 \mathrm{ng} / \mathrm{ul}, 12.0 \mathrm{ng} / \mathrm{ul}$, and $2.0 \mathrm{ng} / \mathrm{ul}$ while the female reference sample yielded $8.0 \mathrm{ng} / \mathrm{ul}$ of total human DNA.

\begin{tabular}{|c|c|c|c|c|}
\hline Subjects & $\mathbf{0 ~ s e c}$ & $\mathbf{1 5} \mathbf{~ m i n}$ & $\mathbf{2} \mathbf{~ h r s}$ & Positive control \\
\hline & $\mathbf{H} / \mathbf{M}$ & $\mathbf{H} / \mathbf{M}$ & $\mathbf{H} / \mathbf{M}$ & $\mathbf{H} / \mathbf{M}$ \\
\hline Assailant 1 & $\mathrm{UD}$ & $3 / 0 \mathrm{pg}^{*}$ & $7 / 10 \mathrm{pg}^{*}$ & $35 \mathrm{ng} / 35 \mathrm{ng}$ \\
\hline Assailant 2 & $7 / 7 \mathrm{pg}$ & $\mathrm{UD}$ & $17 / 8 \mathrm{pg}$ & $12 \mathrm{ng} / 12 \mathrm{ng}$ \\
\hline Assailant 3 & $3 / 0 \mathrm{pg}^{*}$ & $2 / 0 \mathrm{pg}^{*}$ & $5 / 10 \mathrm{pg}^{*}$ & $2 \mathrm{ng} / 2 \mathrm{ng}$ \\
\hline Victim & $5 / 0 \mathrm{pg}$ & $13 / 0 \mathrm{pg}$ & $9 / 0 \mathrm{pg}$ & $8 \mathrm{ng} / 0 \mathrm{ng}$ \\
\hline
\end{tabular}

H/M: total human DNA/male-specific DNA

UD: undetermined

*Male-specific DNA concentration is higher than total human concentration

Table 1: Shedder assessment quantification results for male (assailant) and female (victim) volunteers at three different time intervals and buccal swab reference samples. 
The results from the grab and resist situations on cotton, polyester, and cotton/polyester blend fabric samples are summarized in Table 2. All of the amounts were too low to be significant. The Quantifiler ${ }^{\mathbb{B}}$ Duo kit detected a maximum concentration of $7.0 \mathrm{pg} / \mathrm{ul}$ of total human DNA and $5.0 \mathrm{pg} / \mathrm{ul}$ of male-specific DNA from cotton fabric around the wrist 12 hours post-deposition. Undetermined DNA concentrations were obtained for the other fabric samples, sampling areas, and time intervals. Because of the inability to detect any DNA in the vast majority of samples, variation trends between fabrics and sampling areas could not be analyzed.

\section{Discussion}

This study examined contact DNA recovery from three types of fabrics, at two different time intervals, using an assault model, designed to replicate the touch DNA analysis that might occur in a sexual assault case investigation. We found very little DNA was recovered at any time point from any of the fabrics. We used the Quantifiler ${ }^{\circledR}$ Duo kit, which is considered valid for detecting and quantifying low amounts of DNA ( $<100 \mathrm{pg})$, and concentrated samples prior to quantification, to increase overall yield. In theory, this should improve detectability. However, even after concentrating samples, DNA recovery rates from fabrics were very low and most were undetectable. Our results would not support the use of contact DNA analysis in such settings as we studied. There may be multiple reasons for these results.

Phipps et al. [18] found that an individual might not necessarily shed a consistent amount of DNA over time. Therefore, a given individual may not reliably shed cells that would allow for DNA detection. That may have been the case with our subjects. If we had studied larger numbers of subjects, results might have been somewhat different.

Additionally, increased DNA yields from the shedder could occur when the individual goes longer periods of time without washing hands, which could increase the likelihood of transferring DNA to touched items [16]. Lowe et al. [16] investigated the secondary transfer of low level DNA from individuals to inert surfaces on three different occasions. In each scenario, the potential transfer of DNA from good shedder to poor shedder and via poor shedder to a plastic tube was conducted with a time delay of $0 \mathrm{~min}, 30 \mathrm{~min}$, and 1 hour between the subjects holding hands and gripping tube process. Shedder type assessment and Secondary transfer samples were processed using the same extraction techniques (Qiagen QIAamp ${ }^{\circledR}$ DNA Kit) as the current study. But the extracts were not quantified before amplification unlike this study. However, their profiling results showed that the greatest difference between people and shedder type was observed at $15 \mathrm{~min}$ post-hand washing. Based on that, this study used the 15 minute time interval post-hand washing to maximize DNA deposition and recovery rates.

It is also possible that the fabrics used could have impacted DNA yield and detectability. Since touch DNA is a low copy number template, quantification yields are highly influenced by stochastic effects. Sampling low copy number alleles can cause non-homogeneity in DNA extracts, leading to significant variability in assay results [19]. Though threshold cycles $\left(\mathrm{C}_{\mathrm{T}}\right)$ of $>8$ and $<35$ are desired for successful detection of quantification results [20], fabric samples that produced undetermined yields (below detection threshold) had $\mathrm{C}_{\mathrm{T}}$ values of $>35$, indicating low amounts of target DNA in the sample. Since only a small amount of DNA is transferred during a contact, low or no recovery rates were expected. Our quantification standards, fabric samples, and negative substrate controls showed normal IPC amplification for the set of fabric samples processed after 12 hours of deposition. Our results are consistent with those of Linacre et al. [11] findings of no PCR inhibition from cotton and polyester. However, some of our samples processed after 7 days, showed reduced IPC amplification, indicating possible reaction inhibition. This may be due to the different chemical structures and the various bonding types between fibers. Larkin and Harbison [21] observed that the presence of carbonyl and cyano groups in polyesters allowed for weaker dipole-dipole interactions between nucleic acids and cell membranes. Conversely, the $\mathrm{O}-\mathrm{H}$ groups in cotton tend to form strong hydrogen bonds with nucleic acids, resulting in qualitative differences among fibers.

Bulander and Rolf [22] compared the DNA yield from buccal swabs and touch samples using three commercially available quantification kits for human DNA, including the Applied Bio system's Quantifiler ${ }^{\mathbb{R}}$ and Quantifiler ${ }^{\circledR}$ Duo DNA Quantification kits and Promega's Plexor ${ }^{\circledR}$ HY System, and found that higher absolute values of Y chromosomal DNA were obtained from the Plexor ${ }^{\circledR}$ kit compared to the Quantifiler ${ }^{\circledR}$ Duo kit. Subsequent studies using other quantification kits, such as the Plexor ${ }^{\circledR}$ HY system, might perform better, but should be tested for sensitivity in obtaining male specific DNA concentrations from casework evidence that are anticipated to contain only trace amounts of DNA.

In the investigation of sexual assault cases where clothing is obtained as a potential source of DNA evidence, quantification of touch DNA samples before performing STR analysis can determine the likelihood of obtaining a good profile for the identification of a suspect. Good quantification methods not only determine the unknown DNA concentrations in a sample, but also confirm the presence or absence of human and/or male-specific DNA. Additionally, if quantification

\begin{tabular}{|c|c|c|c|c|c|c|c|c|c|c|}
\hline \multirow{3}{*}{ Subject } & \multirow{3}{*}{ Time interval } & \multicolumn{3}{|c|}{ Cotton } & \multicolumn{3}{|c|}{ Polyester } & \multicolumn{3}{|c|}{ Cotton/Polyester blend } \\
\hline & & Wrist & Elbow & Upper arm & Wrist & Elbow & Upper arm & Wrist & Elbow & Upper arm \\
\hline & & $\mathrm{H} / \mathrm{M}$ & $\mathrm{H} / \mathrm{M}$ & $\mathrm{H} / \mathrm{M}$ & $\mathrm{H} / \mathrm{M}$ & $\mathrm{H} / \mathrm{M}$ & $\mathrm{H} / \mathrm{M}$ & $\mathrm{H} / \mathrm{M}$ & $\mathrm{H} / \mathrm{M}$ & $\mathrm{H} / \mathrm{M}$ \\
\hline \multirow{2}{*}{1} & $12 \mathrm{hrs}$ & $7 / 5 \mathrm{pg}$ & UD & UD & $1 / 0 \mathrm{pg}^{*}$ & UD & UD & $1 / 4 \mathrm{pg}^{*}$ & UD & $2 / 0 \mathrm{pg}^{*}$ \\
\hline & 7 days & UD & UD & UD & UD & UD & UD & UD & UD & UD \\
\hline \multirow{2}{*}{2} & $12 \mathrm{hrs}$ & UD & UD & UD & UD & UD & UD & UD & UD & UD \\
\hline & 7 days & UD & UD & UD & UD & UD & UD & UD & UD & UD \\
\hline \multirow{2}{*}{3} & $12 \mathrm{hrs}$ & UD & UD & UD & UD & UD & UD & UD & UD & UD \\
\hline & 7 days & UD & UD & UD & UD & UD & UD & UD & UD & UD \\
\hline
\end{tabular}

$\mathrm{H} / \mathrm{M}$ : total human DNA/male-specific DNA

UD: undetermined

*Male-specific DNA concentration is higher than total human concentration

Table 2: Quantification results for assailants1, 2, and 3 from cotton, polyester, and cotton/polyester blend fabrics relative to the tested arm areas (wrist, elbow, and upper arm) at two time intervals. 
Citation: Sethi V, Panacek EA, Green WM, Jillian NG, Kanthaswamy S (2013) Yield of Male Touch DNA from Fabrics in an Assault Model. J Forensic Res T1: 001. doi:10.4172/2157-7145.T1-001

Page 4 of 4

results cannot aid in determining the amount of sample to be used for STR analysis, it can still determine whether STR analysis should be done, which may help cut down the costs involved in the purchase and analysis of expensive human STR typing kits.

In addition to any limitations noted above, the findings of this study may be limited by small sample size. We only studied three "assailant" subjects and only three different fabrics. Other studies with larger sample size or using different techniques might yield better results. However, we used the techniques currently available that were thought to have the best chance of a positive yield.

In summary, this model of an assault, using these fabrics and DNA analysis approach did not find sufficient amounts of touch DNA that could be used to generate a useful profile. The quantification results in this study lie outside of the Quantifiler ${ }^{\circledR}$ Duo's standard curve (lowest quantification standard data point is $23 \mathrm{pg} / \mathrm{ul}$ ) and would not support the routine use of touch DNA analysis from clothing in similar settings.

\section{Acknowledgement}

I would like to acknowledge the volunteers for participating and contributing DNA samples that led to the success of this project. And, I am most thankful to Forensic Science Department of University of California, Davis for providing financial support to this research.

\section{References}

1. Gill P, Whitaker J, Flaxman C, Brown N, Buckleton J (2000) An investigation of the rigor of interpretation rules of STRs derived from less than $100 \mathrm{pg}$ of DNA. Forensic Sci Int 112: 17-40.

2. Paula WH (2008) Low Copy Number DNA: Reality vs. Jury Expectations. National District Attorney's Association American Prosecutors Research Institute 10.

3. Wickenheiser RA (2002) Trace DNA: a review, discussion of theory, and application of the transfer of trace quantities of DNA through skin contact. $J$ Forensic Sci 47: 442-450.

4. Pizzamiglio M, Donato F, Floris T, Bellino C, Cappiello P, et al. (2000) DNA typing on latex gloves. In Progress inForensic Genetics. Sensabaugh GF, Lincoln PJ, Olaisen B (eds.) Elsevier: Amsterdam, The Netehrlands 8: 504-507.

5. Tsuchihashi $Y(1974)$ Studies on personal identification by means of lip print. Forensic Sci Int 3: 233-248.

6. Schiffner L, Bajda JE, Prinz M, Sebestyen J, Shaler R, et al. (2005) Optimization of a Simple, Automatable Extraction Method to Recover Sufficient DNA from Low Copy Number DNA Samples for Generation of Short Tandem Repeat Profiles. Croat Med J 46: 578-586.
7. Daly DJ, Murphy C, McDermott SD (2012) The transfer of touch DNA from hands to glass, fabric and wood. Forensic Science International: Genetics 6: 41-46.

8. Van Oorschot RAH, Jones MK (1997) DNA fingerprints from fingerprints Nature 387: 767 .

9. Schulz MM, Reichert W (2000) A strategy for STR-analysis of cryptic epithelia cells on several textiles in practical casework. In: Sensabaugh GF, Lincoln PJ, Olaisen B (eds.) Progress in forensic genetics. Elsevier: Amsterdam, The Netherlands 8: 514-516.

10. Gill P (2001) Amplification of low copy number DNA profiling. Croat Med J 42 229-232.

11. Linacre A, Pekarek V, Swaran YC, Tobe SS (2010) Generation of DNA profiles from fabrics without DNA extraction. Forensic Sci Int Genet 4: 137-141.

12. Webb LG, Egan SE, Turbett GR (2001) Recovery of DNA for Forensic Analysis from Lip Cosmetics. J Forensic Sci 46: 1474-1479.

13. Aljanabi SM, Martinez I (1997) Universal and rapid salt-extraction of high quality genomic DNA for PCR-based techniques. Nucleic Acids Res 25: 4692-4693.

14. Sambrook J, Russell DW (2001) Molecular Cloning, a Laboratory Manual. Cold Spring Harbor Laboratory Press: NY, USA.

15. KremserA, Bayer B, Jung S, Anslinger K (2009) Quantifiler ${ }^{\circledR}$ Human DNA Quantification Kit (Applied Biosystems) as a screening kit for DNA profiling Forensic Science International: Genetics Supplement Series: 106-107.

16. Lowe A, Murray C, Whitaker J, Tully G, Gill P (2002) The propensity of individuals to deposit DNA and secondary transfer of low level DNA from individuals to inert surfaces. Forensic Sci Int 129: 25-34.

17. Raymond JJ, Van Oorschot RAH, Gunn PR, Walsh SJ, Roux C (2009) Trace evidence characteristics of DNA: A preliminary investigation of the persistence of DNA at crime scenes. Forensic Science International: Genetics 4: 26-33.

18. Phipps M, Petricevic S (2007) The tendency of individuals to transfer DNA to handled items. Forensic Sci Int 168: 162-168.

19. Applied Biosystems (2012) Quantifiler ${ }^{\circledR}$ Duo DNA Quantification Kit User's Manual. USA.

20. Applied Biosystems (2010) Absolute QuantitationUsing Standard CurveGetting Started Guide for 7500/7500 Fast Real Time PCR System. USA

21. Larkin A, Harbison S (1999) An improved method for STR analysis of bloodstained denim. Int J Legal Med 112: 388-390.

22. Bulander N, Rolf B (2009) Comparison of the Plexor ${ }^{\circledR}$ HY System, Quantifiler ${ }^{\circledR}$ and Quantifiler Duo ${ }^{\circledR}$ kits using the Roche LightCycler 480 System and the ABI 7900 real time PCR instrument. Forensic Science International: Genetics Supplement Series 2: 104-105. 